\title{
PHYSICAL AND CHEMICAL RESEARCH IN VELEBITA PIT (CROATIA)
}

\author{
FIZIKALNO KEMIČNE RAZISKAVE V BREZNU VELEBITA \\ (HRVAŠKA)
}

\author{
Dalibor PAAR ${ }^{1,5}$, Magdalena UJEVIĆ ${ }^{2}$, Darko BAKŠIĆC ${ }^{3,5}$, Damir LACKOVIĆC ${ }^{4,5}$, \\ Ana ČOP ${ }^{5} \&$ Vanja RADOLIĆ ${ }^{6}$
}

\begin{abstract}
UDC 551.44(497.5):546.296

Dalibor Paar, Magdalena Ujević, Darko Bakšić, Damir Lacković, Ana Čop \& Vanja Radolić: Physical and Chemical Research in Velebita pit (Croatia)

We have performed measurements of the cave microclimate, water quality parameters and radon concentration to a depth of $-1000 \mathrm{~m}$ in Velebita Cave system (Northern Velebit, Croatia). The results were analyzed as a function of the cave depth and geomorphological characteristics. Two different air temperature gradients were obtained, which can be attributed to a cave morphology and air circulation in the upper part of the pit. The water quality parameters show that the studied waters are poorly mineralized and are of weakly alkaline type. Water chemistry is probably predominantly controlled by the petrography of the bedrock (limestone) and the cave morphology. Water in the cave is not affected by pollution. The average value of radon concentration is rather low, much lower than in some other Croatian caves.
\end{abstract}

Keywords: Cave climate, pH, TDS, conductivity, ORP, radonconcentration, Mt.Velebit, Croatia.
Izvleček UDK 551.44(497.5):546.296

Dalibor Paar, Magdalena Ujević, Darko Bakšić, Damir Lacković, Ana Čop \& Vanja Radolić: Fizikalno kemične raziskave v breznu Velebira (Hrvaška)

$\mathrm{V}$ jamskem sistemu Velebita (Severni Velebit, Hrvaška), smo do globine $1000 \mathrm{~m}$ merili klimatske in hidrološke parametre ter koncentracijo radona. Rezultate smo interpretirali z ozirom na globino in morfološke značilnosti jame. $\mathrm{V}$ jami smo izmerili dva različna temperaturna gradienta, ki jih povezujemo z jamsko morfologijo in kroženjem zraka $\mathrm{v}$ zgornjem delu brezna. Fizikalno-kemični parametri vode kažejo na nizko mineralizacijo sicer šibko alkalne vode. Kemija vode je v glavnem odvisna od petrografskih značilnosti kamnine (apnenec) in morfologijo jame oz. vodnih poti. Voda $\mathrm{v}$ jami ni onesnažena. Povprečna vrednost koncentracije radona je nizka, vsekakor nižja od drugih jam na Hrvaškem..

Ključne besede: Jamska klima, pH, TDS, specifična električna prevodnost, koncentracija radona, Velebit, Hrvaška.

\section{INTRODUCTION}

Northern Velebit is a mountainous region in Croatia between the Adriatic Sea and Ličko-Gacko Polje. The characteristics of this region place Mt. Velebit to alpine karst. Alpine karst is an important, but also very vulnerable natural resource with large amounts of groundwater stored in its depths. Alpine karst aquifers are complex and very vulnerable systems. To asses the vulnerability of alpine karst water resources and plan their protection, it is necessary to analyze water dynamics, the quality and the diverse characteristics of these systems (Petrič

\footnotetext{
${ }^{1}$ Faculty of Science and Mathematics, Bijenička 32, Zagreb, Croatia, dpaar@phy.hr

${ }^{2}$ Croatian National Institute of Public Health, Rockefellerova 7, Zagreb, Croatia

${ }^{3}$ Faculty of Forestry, Svetošimunska 25, Zagreb, Croatia

${ }^{4}$ Croatian Natural History Museum, Demetrova 1, Zagreb, Croatia

${ }^{5}$ Speleological Section Velebit, Radićeva 23, Zagreb, Croatia

${ }^{6}$ Department of Physics, University of Osijek, P.O. Box 125, Osijek, Croatia

Received/Prejeto: 9.9.2008
} 
2004, Ravbar 2007). As in Slovenia, alpine karst waters in Croatia can be a very important water resource in the future. The amount and quality of groundwater stored in its depths should be explored. The quality of groundwater is largely affected by processes occurring in the vadose zone of karstic aquifers. Deep and accessible pits provide excellent natural laboratories for these investigations.

\section{GEOMORPHOLOGICAL CHARACTERISTICS OF VELEBITA PIT}

The Northern Velebit karst area is conducive to the formation of deep pits, three of which are deeper than $1 \mathrm{~km}$ - Lukina Jama Cave (-1392 m), Slovačka Jama (-1320 m) and the recently discovered Cave system Velebita (-1026 $\mathrm{m})$. So far, 259 pits have been discovered in the Northern Velebit area, which extends over some 25 square kilometers (Bakšić\&Paar 2006). This area is composed of lithostratigraphic units ranging from the Middle Triassic to the Paleogene age. The largest part of Northern Velebit is composed of Jurassic sediments which contain carbonate rocks only. Limestone prevails in the composition of deposits, but dolomites are also present. Jurassic deposits are approximately 2,850 m thick. However, speleological explorations have revealed more complex geology of Northern Velebit. For example, Lukina Jama contains deposits of carbonate breccias from -450 to $-700 \mathrm{~m}$ and from -750 to $-950 \mathrm{~m}$. A similar situation occurs in Slovačka Jama as well. This poses a number of questions related to their stratigraphy and tectonic movements (Lacković et al. 1999). A significant part of the subject area is covered with the Jelar formation of the Upper Paleogene age. Its origin is closely related to strong tectonic movements affecting the area at that time (Bahun 1974). In the hinterland (Lika) calcareous breccias are partially permeable but in the higher positions on Northern Velebit they are highly permeable. Calcareous breccias are up to $300 \mathrm{~m}$ thick (Kuhta \& Bakšić 2001).

The morphology of the Cave system Velebita is complex to the depth of $-228 \mathrm{~m}$. The entrance to Velebita pit descends between lodged boulders to the entrance chamber. The cave continues with the shaft after a passage between the boulders and the compact rock on the floor. The entrance to Dva Javora (Two Maples) pit is a vertical crack of $5 \times 0.5 \mathrm{~m}$ situated $66 \mathrm{~m} \mathrm{NW}$ and $7.3 \mathrm{~m}$ below the entrance to Velebita pit. At a depth of $-74 \mathrm{~m}$, in the southern part of the main passage, there is a large passage to a parallel meander which goes back southwards to the neighboring pit Breskva. In Dva Javora there is also another vertical part down to $-228 \mathrm{~m}$.

The entrance parts of Velebita are in the S-N and S/SW - N/NE directions, while the entrance parts of Dva Javora are in the W-E direction. At the contact of the passages (meanders) in Dva Javora and Velebita stretching through high and wide cracks in the W-E and the S-N directions, there is an entrance to the shaft of Divka Gromovnica (the total shaft length is $513 \mathrm{~m}$ ). The bottom part of the shaft at $-574 \mathrm{~m}$ ends with a sloped chamber covered with big boulders. In the southern part of the chamber there is a $10 \mathrm{~m}$ wide, shallow drip-water pool, and in the south-eastern part there is another small shallow drip-water pool with a small stream flowing to the bottom of the chamber.

In the southern rock of the Divka Gromovnica shaft at $-534 \mathrm{~m}$ there is a meander in the south direction going down to Bivouac 2 at $-786 \mathrm{~m}$. In the vicinity of this point there is an incoming shaft with a stream of water which is strong during rainy weather. The stream continues to the main passage, which goes down to $-941 \mathrm{~m}$. After the "Ljutiša" waterfall at $-941 \mathrm{~m}$, it joins the SW passage with another incoming water stream from the north direction. Down to the stream is a meander finishing with the "Podzemljar" Chamber of $70 \times 60 \mathrm{~m}$, whose bottom is at a depth $-1026 \mathrm{~m}$.

\section{MATERIALS AND METHODS}

In situ measurements of water $\mathrm{pH}$, specific electric conductivity (COND), total dissolved solids (TDS), oxidation reduction potential (ORP) and temperature were performed in 14 measuring points in Velebita pit using the Ultrameter II 6P Myron device. Measurements were performed during an expedition in Velebita pit (5 - 12 Aug 2007).

Two water samples were taken for laboratory analysis at the Croatian National Institute of Public Health. Bicarbonate was determined by titration with $\mathrm{HCl}$ and 


\section{Cave system Velebita}

North Velebit, Croatia

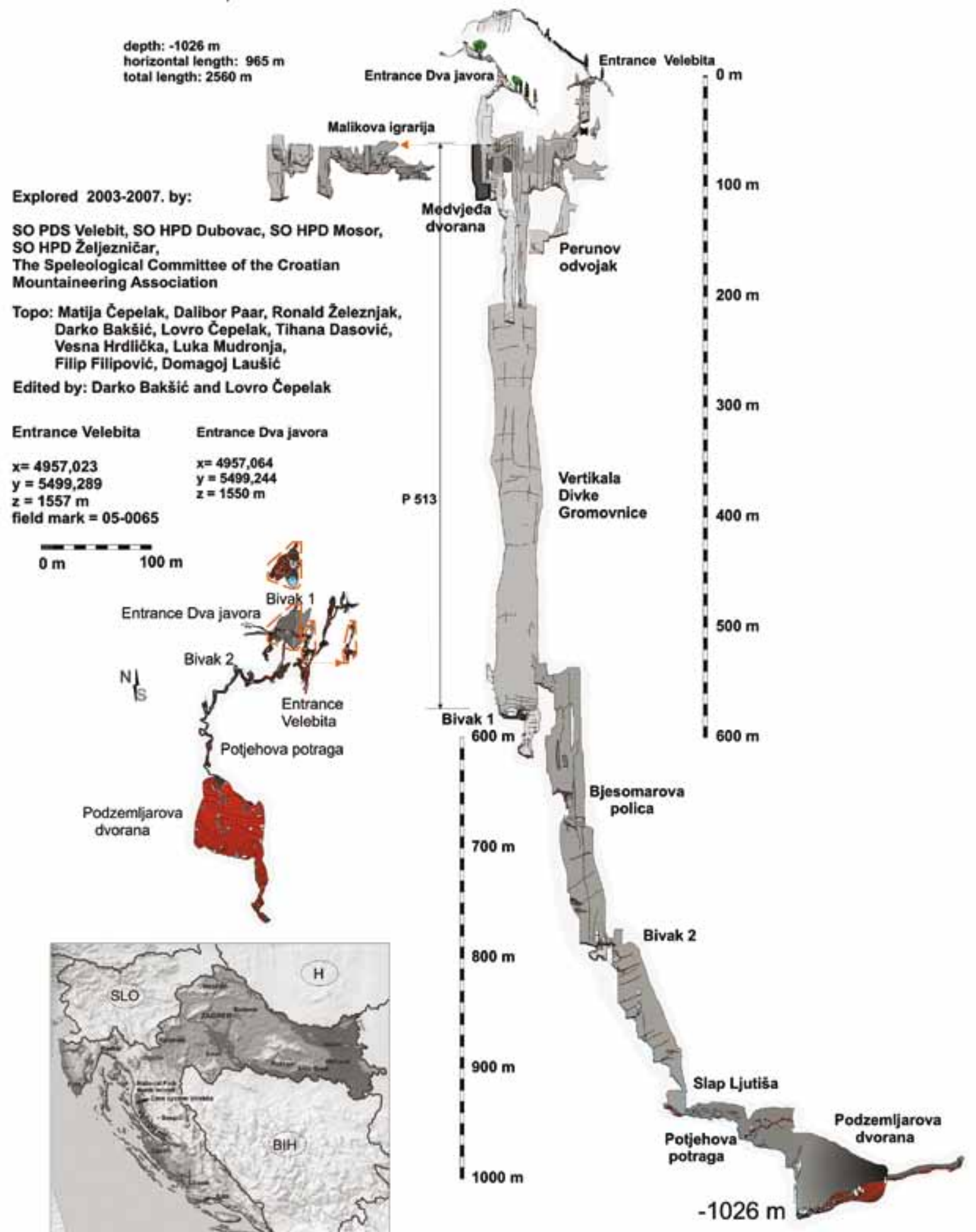

Fig. 1: Velebita Cave system. Insert: Location of the cave. 
methyl orange as an indicator. An ICS 500 ion chromatography system (Dionex) was used to determine major anions (sulphate, chloride and nitrate) and cations (sodium, potassium, calcium and magnesium) concentrations.

Microclimatic parameters were measured with Onset Hobo Temp/RH and Oakton RH/Temp data loggers. Airflow was measured with Silva Alba wind watch.

Integrated measurements of radon and its shortlived progenies in the air were performed by means of the passive track etching method with the LR-115 SSNT detector, type II (Kodak-Pathé, France) at 10 measuring sites. The cylindrical detector cup, with the diameter and length of $11 \mathrm{~cm}$ and $7 \mathrm{~cm}$ respectively, was either covered with a paper filter of $0.078 \mathrm{~kg} / \mathrm{m}^{2}$ surface density (diffusion detector), or was open. Radon concentration in the air was determined as a product of the sensitivity coefficient and track density of the diffusion detector. The measurement method with two detectors (diffusion and open one) enables determination of the equilibrium factor for radon and its progeny in the air (Planinić et al. 1997).

\section{RESULTS OF MEASUREMENTS AND DISCUSSION}

\section{MICROCLIMATE CONDITIONS}

In order to obtain a complete picture of microclimatic parameters, monitoring should be undertaken over an extended period of time (Cigna 2002). However, deep pits such as Velebita do not allow this due to a very complex access to the measuring points. Consequently, the cave microclimatic parameters were monitored during

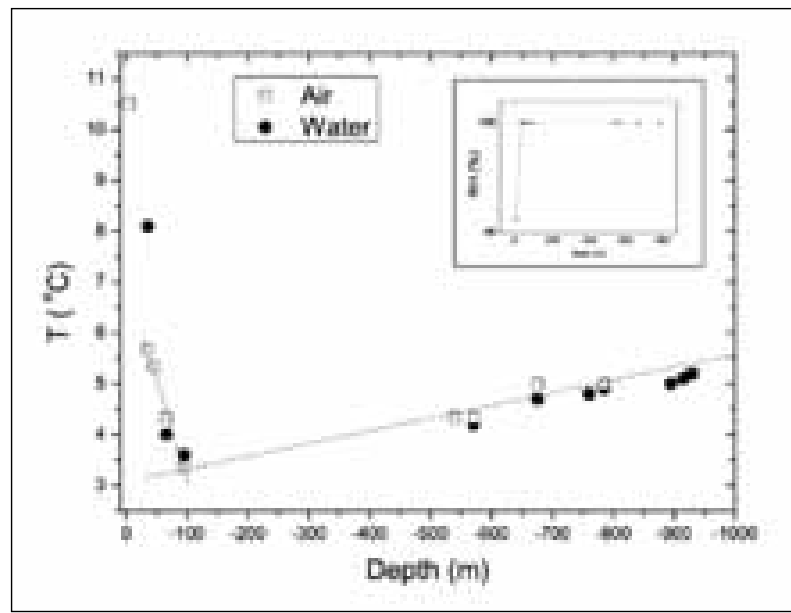

Fig. 2: Air and water temperature variation with the cave depth (5.-12.8.2007.). Dashed lines are two different linear regressions of air temperature between -30 and $-100 \mathrm{~m}$, and -100 and -800 m. Insert: Relative air humidity $\mathrm{RH} \%$ as a function of the cave depth.

Table 1: Air and water temperature gradients

\begin{tabular}{|c|c|c|}
\hline & Depth & Temperature gradient \\
\hline Air & -30 to $-100 \mathrm{~m}$ & $\mathrm{dT} / \mathrm{dh}=-3.5 \pm 0.2 \mathrm{oC} / 100 \mathrm{~m}$ \\
\hline Air & -100 to $-800 \mathrm{~m}$ & $\mathrm{dT} / \mathrm{dh}=+0.25 \pm 0.03 \mathrm{oC} / 100 \mathrm{~m}$ \\
\hline Water & -100 to $-900 \mathrm{~m}$ & $\mathrm{dT} / \mathrm{dh}=+0.19 \pm 0.02 \mathrm{oC} / 100 \mathrm{~m}$. \\
\hline
\end{tabular}

speleological exploration. The temperature and relative humidity of the cave atmosphere were measured at 14 locations throughout the cave (Fig. 2). Relative air humidity in the entrance chamber of Velebita was $95.6 \pm 6.3 \%$, and at other measuring points it was close to $100 \%$.

The highest air temperature with the average value $10.5 \pm 1.1^{\circ} \mathrm{C}$ was recorded in the entrance chamber. The temperature falls to $3.4^{\circ} \mathrm{C}$ at a depth of $-95 \mathrm{~m}$. In the shaft of Divka Gromovnica the temperature rises to $4.3^{\circ} \mathrm{C}$ at the bottom of the shaft at $-570 \mathrm{~m}$ and continues to rise at a rate given in Table 1 . Water temperature also rises at a lower rate.

At the entrance to the first shaft in Velebita pit, the air flow changes with a maximum speed of $2.5 \pm 0.2 \mathrm{~m} / \mathrm{s}$. At $-35 \mathrm{~m}$, air flow with change of direction was detected with period between 10 and 20 seconds. The maximum speed was $5.6 \pm 0.2 \mathrm{~m} / \mathrm{s}$ (direction: cold air going out) and $3.5 \pm 0.1 \mathrm{~m} / \mathrm{s}$ (direction: hot air going in).

\section{WATER QUALITY}

Water quality parameters were measured in situ at 14 locations in the cave (Table 2). The $\mathrm{pH}$ of meteoric water (collected at the surface) is $6.98 \pm 0.01$, and in the cave it slightly decreases with the depth, and it is between 8.0 and 8.35 at maximum. The oxidation reduction potential (ORP) value decreases with the depth at a rate -5.5 $\pm 0.7 \mathrm{mV} / 100 \mathrm{~m}$. The lowest value of $186 \pm 1 \mathrm{mV}$ is at $-930 \mathrm{~m}$. The ORP value of meteoric water $206 \pm 1 \mathrm{mV}$ is comparable with the value in the cave at $-760 \mathrm{~m}$.

The specific electrical conductivity (COND) gives general information on water chemistry. The average value of COND is $182 \pm 25 \mu \mathrm{S} / \mathrm{cm}$ and does not show any sig- 
Table 2: In-situ measurements of water quality parameters

At depth 0 the meteoric water sample is collected on the surface (rainwater).

\begin{tabular}{|c|c|c|c|c|c|}
\hline $\begin{array}{c}\text { Location: } \\
\text { Depth }(\boldsymbol{m})\end{array}$ & $\boldsymbol{p H}$ & $\begin{array}{c}\text { COND } \\
(\boldsymbol{\mu S} / \mathbf{c m})\end{array}$ & $\begin{array}{c}\text { ORP } \\
\boldsymbol{m} \boldsymbol{V}\end{array}$ & $\begin{array}{c}\text { TDS } \\
\boldsymbol{p p m}\end{array}$ & $\begin{array}{c}\boldsymbol{T} \\
\left.\boldsymbol{(}^{\circ} \boldsymbol{C}\right)\end{array}$ \\
\hline 0 & 6.98 & 13.12 & 436 & 8.33 & 15.9 \\
\hline-35 & 7.95 & 183 & 492 & 120.9 & 8.1 \\
\hline-65 & 8.22 & 178.5 & 459 & 118.7 & 4.0 \\
\hline-95 & 8.35 & 206.2 & 465 & 137.8 & 3.6 \\
\hline-390 & 8.11 & 178.5 & 466 & 118.2 & 5.9 \\
\hline-570 & 8.19 & 156.3 & 467 & 103.5 & 4.3 \\
\hline-570 & 8.22 & 153.1 & 460 & 101.4 & 4.2 \\
\hline-570 & 8.28 & 177.8 & 463 & 118.3 & 4.2 \\
\hline-675 & 8.20 & 192.4 & 469 & 128.0 & 4.7 \\
\hline-760 & 8.14 & 181.5 & 434 & 120.6 & 4.8 \\
\hline-785 & 8.10 & 260.6 & 430 & 173.4 & 4.8 \\
\hline-895 & 8.09 & 171.9 & 429 & 113.9 & 5.0 \\
\hline-915 & 8.07 & 166.8 & 423 & 110.4 & 5.1 \\
\hline-930 & 8.19 & 169.5 & 416 & 112.1 & 5.2 \\
\hline
\end{tabular}

Table 3: Chemical analysis of two water samples: a) water sample taken at $-584 \mathrm{~m}$,

b) at $-920 m$ in Velebita pit.

\begin{tabular}{|c|c|c|c|c|c|c|c|c|}
\hline $\begin{array}{l}\text { Location: } \\
\text { Depth }(\mathbf{m})\end{array}$ & $\mathrm{HCO}_{3}^{-}$ & $\mathbf{C l}$ & $\mathbf{N O}_{\mathbf{3}}^{-}$ & $\mathbf{S O}_{4}{ }^{2-}$ & $\mathbf{N a}^{+}$ & $\boldsymbol{K}^{+}$ & $\mathbf{M g 2}^{+}$ & $\mathbf{C a}^{2+}$ \\
\hline & $\gamma(\mathrm{mg} / \mathrm{L})$ & $\gamma(\mathrm{mg} / \mathrm{L})$ & $\gamma(\mathrm{mg} / \mathrm{L})$ & $\gamma(\mathrm{mg} / \mathrm{L})$ & $\gamma(\mathrm{mg} / \mathrm{L})$ & $\gamma(\mathrm{mg} / \mathrm{L})$ & $\gamma(\mathrm{mg} / \mathrm{L})$ & $\gamma(\mathrm{mg} / \mathrm{L})$ \\
\hline a) -584 & 92.4 & 1.56 & 3.58 & 2.74 & 0.5 & 0.05 & 0.12 & 33 \\
\hline b) -920 & 105.2 & 1.71 & 4.16 & 2.92 & 0.77 & 0.08 & 0.19 & 36.7 \\
\hline
\end{tabular}

saturated with calcite $(\mathrm{SIc}=$ -0.04) while water at $-920 \mathrm{~m}$ is lightly saturated with calcite $($ SIc $=0.03)$. The observed SIc values are very close to equilibrium $(\mathrm{SI}=0)$. Waters at $-584 \mathrm{~m}$ and $-920 \mathrm{~m}$ were unsaturated regarding to dolomite (SId $=-2.50$ and -2.21 respectively).

\section{RADON CONCENTRATION}

Radon is a naturally occurring radioactive gas that is produced in the radioactive decay of uranium and other elements. Radon concentration measurements were performed in the upper part of Velebita pit and. The results are given in Table 4 . The measurement time was defined by cave exploration, 9 days for the locations down to $100 \mathrm{~m}$, and 6 days for deeper locations. We can interpret these results as measures of lower radon concentrations in the cave. nificant differences between waters from different locations. However, electric conductivity has a lower value $153 \pm 0.1 \mu \mathrm{S} / \mathrm{cm}$ at a depth $-570 \mathrm{~m}$ and the highest value $260.6 \pm 0.1 \mu \mathrm{S} / \mathrm{cm}$ at $-785 \mathrm{~m}$. The observed changes reflect the impact of cave litology, geomorphology and the mixing of waters from different flows on water chemistry. Total dissolved solids (TDS) also have the lowest value of $101.4 \pm 0.1 \mathrm{ppm}$ at $-570 \mathrm{~m}$, and the highest value of $173.4 \pm 0.1 \mathrm{ppm}$ at $-785 \mathrm{~m}$. The COND and TDS values of meteoric water are about 10 to 20 times lower than the values in the cave.

Data related to the chemical content for only two samples are available (Table 3); however, some general statements can be pointed out. The concentration in $\mathrm{Ca}^{2+}$ largely exceeds that of $\mathrm{Mg}^{2+}, \mathrm{Na}^{+}$and $\mathrm{K}^{+}$. The predominant anion is $\mathrm{HCO}_{3}^{-}$so water in the cave is of $\mathrm{Ca}-\mathrm{HCO}_{3}$ type. This water type reflects the predominant rock type in the cave - limestone. Even if dolomite can be present too due to short water-rock interaction time, $\mathrm{Mg}$ concentrations are low. Water at $-584 \mathrm{~m}$ is lightly un-
Table 4: Measurements of radon concentration $c$ and equilibrium constant $F$ at various depths in Velebita pit

\begin{tabular}{|c|c|c|}
\hline $\begin{array}{c}\text { Location: } \\
\text { Depth }(\boldsymbol{m})\end{array}$ & $\boldsymbol{c} \pm \boldsymbol{\sigma}_{\boldsymbol{c}}\left(\mathbf{B q} \mathbf{m}^{-3}\right)$ & $\boldsymbol{F} \pm \boldsymbol{\sigma}_{\boldsymbol{F}}$ \\
\hline-5 & $96 \pm 36$ & \\
\hline-38 & $112 \pm 39$ & $0.62 \pm 0.38$ \\
\hline-68 & $421 \pm 53$ & \\
\hline-86 & $255 \pm 45$ & $0.20 \pm 0.13$ \\
\hline-94 & $24 \pm 35$ & \\
\hline-157 & $319 \pm 67$ & $0.56 \pm 0.22$ \\
\hline-207 & $269 \pm 64$ & $0.43 \pm 0.22$ \\
\hline-227 & $408 \pm 69$ & $0.36 \pm 0.15$ \\
\hline-294 & $192 \pm 61$ & $0.91 \pm 0.40$ \\
\hline-370 & $456 \pm 71$ & \\
\hline
\end{tabular}




\section{CONCLUSIONS}

The results were analyzed as a function of cave depth and geomorphological characteristics. Two air temperature gradients were obtained: $\mathrm{dT} / \mathrm{dh}=-3.9 \pm 0.2^{\circ} \mathrm{C} / 100 \mathrm{~m}$ and $+0.25 \pm 0.03^{\circ} \mathrm{C} / 100 \mathrm{~m}$. Since at about $-100 \mathrm{~m}$ there is an entrance to a $513 \mathrm{~m}$ long shaft, this change can be attributed to a cave morphology and detected air circulation in the upper part of the pit. In the upper part of the pit, air circulation changes the temperature gradient by condensation or evaporation that is releasing or absorbing the heat. In the lower part, the temperature increases with depth because of Earth's geothermal gradient. It is also shown, that small water masses flowing into a mountain are able to peturb the rock temperature (Badino 2005).

The water quality parameters measured in situ at 14 locations in the cave show that the studied waters are poorly mineralized and weakly alkaline. Oxidation reduction potential (ORP) shows clear reduction in the value with depth, while the calculated rate is $-5.5 \pm$ $0.7 \mathrm{mV} / 100 \mathrm{~m}$. Water chemistry is probably predominantly controlled by the petrography of the bedrock (limestone) and the cave morphology. Chemical analyses of water performed on two samples show that waters are $\mathrm{Ca}-\mathrm{HCO}_{3}$ type. Low concentrations of $\mathrm{NO}_{3}{ }^{-}, \mathrm{Cl}^{-}, \mathrm{SO}_{4}{ }^{2-}, \mathrm{K}$ and $\mathrm{Na}$ suggest that the water in the cave is not affected by pollution. However, more frequent and continuous research should be undertaken in order to determine factors which control the chemical composition of water.

The average value of radon concentration from the entrance down to a depth of $-100 \mathrm{~m}$ is $181.6 \pm 41.6 \mathrm{~Bq} / \mathrm{m}^{3}$, and between $-100 \mathrm{~m}$ and $-400 \mathrm{~m}$ is $328.8 \pm 66.4 \mathrm{~Bq} / \mathrm{m}^{3}$. Radon concentrations are much lower than in some other Croatian caves, where concentrations up to $14.400 \mathrm{~Bq} / \mathrm{m}^{3}$ were measured (Paar et al. 2005).

\section{ACKNOWLEDGEMENTS}

The authors would like to thank to North Velebit National Park and Croatian waters for the support of presented work. Their thanks also go to the members of the Spe- leological Section Velebit, Zagreb, for their assistance in field work.

\section{REFERENCES}

Badino, G., 2005: Underground drainage systems and geothermal flux. Acta carsologica, 34/2, 277-316, Ljubljana.

Bahun, S., 1974: The tectogenesis of Mt. Velebit and the formation of Jelar deposits. Geološki vjesnik 27, Zagreb : 35-51.

Bakšić, D. \& Paar, D., 2006: Croatia and the Deep Caves of Northern Velebit. Alpine Karst, vol 2., ed. J. \& T. Oliphant, 105-124, Cave books, Dayton, USA.

Cigna, A.A., 2002: Modern trend in Cave monitoring. Acta carsologica 31/1, 35-54, Ljubljana.

Kuhta, M. \& Bakšić, D., 2001: Karstification Dynamics and Development of the Deep Caves on the North Velebit Mt. - Croatia. $13^{\text {th }}$ Internatinal Congress of Speleology, 1-4, Brazil.

Lacković, D., Šmida, B., Horvatinčić, N. \& Tibljaš, D., 1999: Some geological observations in Slovačka jama cave $(-1268 \mathrm{~m})$ in Velebit mountain, Croatia. Acta carsologica 28/2, 113-120, Ljubljana.
Paar, D., Radolić, V. \& Buzjak, N., 2005: Measurements of concentration of radioactive gas radon in the caves of Žumberak. Znanstveno-stručni skup istraživača krša Žumberačke gore, 20, Bregana.

Petrič, M., 2004: Alpine karst waters in Slovenia. Acta carsologica 33/1, 11-24, Ljubljana.

Planinić, J., Radolić, V., Faj, Z. \& Šuveljak, B., 1997: Radon equilibrium factor and aerosols. Nuclear Instruments and Methods A, 396, 414-417.

Ravbar, N., 2007: The protection of karst waters - a comprehensive Slovene Approach to vulnerability and contamination risk mapping. Carsologica 6 - series ed. F. Gabrovšek. Postojna-Ljubljana. 